\title{
EFEKTIVITAS METODE PROBLEM SOLVING TERHADAP HASIL BELAJAR MATEMATIKA KELAS IV SD ISLAM AL-AZHAR 47 SAMARINDA PADA MASA PANDEMI COVID-19
}

\author{
Didink Agustien, Abdul Razak \\ IAIN, Samarinda, Indonesia \\ didinkagustien52@gmail.com \\ 085643672019 \\ Abdul Razak \\ IAIN, Samarinda, Indonesia \\ razakabdul180290@gmail.com \\ 085386894539
}

\begin{abstract}
Abstrak
Penelitian ini bertujuan untuk mengetahui seberapa besar metode problem solving efektif pada hasil belajar matematika kelas IV SD Islam Al-Azhar 47 Samarinda pada masa pandemi covid-19. Latar belakang dalam penelitian ini adalah kurangnya kesenangan siswa pada mata pelajaran matematika, strategi pembelajaran yang kurang tepat dan kurangnya pengembangan kreativitas siswa dalam proses pembelajaran. Jenis penelitian ini adalah penelitian kuantitatif. Teknik pengumpulan data menggunakan observasi, tes dan dokumentasi. Teknik analisis data dalam penelitian ini menggunakan uji normalitas, uji homogenitas dan uji hipotesis. Teknik pengujian keabsahan data dengan menggunakan uji validitas dan uji reliabilitas. Hasil penelitian menunjukkan bahwa rata-rata nilai hasil belajar matematika metode problem solving lebih tinggi daripada nilai hasil belajar matematika metode konvensional. Hasil uji normalitas pada hasil pretest kelompok eksperimen memiliki taraf signifikansi sebesar 0,409 dan hasil posttest memiliki taraf signifikansi sebesar 0,72. Sedangkan hasil pretest kelompok kontrol memiliki taraf signifikansi sebesar 0,16 dan hasil posttest memiliki taraf signifikansi sebesar 0,594. Hasil rekapitulasi uji homogenitas hasil belajar matematika pada kelas eksperimen dan kontrol diperoleh nilai signifikansi sebesar 0,913. Hasil posttest uji independent t-test pada kelompok eksperimen dan kelompok kontrol dengan $t$ hitung sebesar 0,074 > dari t tabel sebesar 2,021 (Df ke 40) atau nilai signifikansi yang diperoleh sebesar 0,074 lebih kecil dari taraf signifikansi 0,05, maka dapat dinyatakan bahwa Ha diterima dan Ho ditolak. Dapat disimpulkan bahwa metode problem solving efektif digunakan pada mata pelajaran matematika pokok bahasan bangun datar.
\end{abstract}

Kata kunci: problem solving, hasil belajar matematika, pandemi covid-19

\section{PENDAHULUAN}

Pendidikan adalah usaha yang dilakukan dengan tujuan untuk menumbuh kembangkan potensi peserta didik melalui proses kegiatan belajar mengajar. Dengan melihat keadaan bahwa ada dua masalah yang dihadapi yaitu, mutu pendidikan dan sistem pembelajaran di sekolah. Pengertian pendidikan sendiri adalah suatu proses yang sudah dilakukan yang sudah menjadi satu dalam kehidupan dunia, sebab dengan adanya pendidikan yang baik, manusia akan meraih dan menguasai pengetahuan yang ia dapatkan. Dengan adanya 
pendidikan seseorang akan yang sebelumnya tidak mengetahui apa-apa menjadi mendapatkan ilmu yang bermanfaat.

Matematika mempunyai peranan yang penting dalam dunia pendidikan. Dengan adanya mata pelajaran matematika, maka kita akan belajar bernalar secara kritis, kreatif dan aktif. Pembelajaran matematika dapat dikatakan berhasil jika pembelajaran tersebut sesuai dengan tujuan pengajaran matematika dan siswa terlihat dalam menguasai mata pelajaran matematika. Dalam pembelajaran matematika tugas seorang guru sangatlah penting. Adapun tugas seorang guru adalah dapat membangkitkan suasana pembelajaran yang lebih bermakna dengan mengaitkan pada kehidupan sehari-hari. Dengan demikian pembelajaran matematika mempunyai peranan yang sangat penting dengan cara pembuktian yang nyata. Hal ini sejalan dengan Sriyanto yang menyatakan bahwa "mathematics is a way of thinking a way of reasoning. Some of mathematics involves experimentation and observation, but most of mathematics is concerned with deductive reasoning”. Matematika adalah suatu cara berpikir melalui pembuktian. ${ }^{1}$ Beberapa matematika melibatkan suatu eksperimen, tetapi hampir semua bagian matematika berhubungan dengan pembuktian. Menurut Hasan Sastra Negara bahwa matematika adalah suatu pelajaran yang melibatkan suatu eksperimen yang hampir semua bagian matematika berhubungan dengan pembuktian. ${ }^{2}$ Menurut Sitti Rahayu dan Wahyu Nur Hidayati dalam jurnal bahwa dengan perkembangan IPTEK yang pesat adalah karena adanya dukungan dari matematika. ${ }^{3}$ Menurut Hikmah dalam jurnal saintifik bahwa sasaran atau obyek penelahaan matematika adalah fakta, operasi dan prinsip. Matematika digunakan sebagai alat yang dapat membentuk pemikiran seseorang. ${ }^{4}$ Karena bermanfaat dalam kehidupan sehari-hari serta kemajuan pengembangan ilmu pengetahuan teknologi. Selanjutnya menurut Muhammad Daut Siagian tentang journal of mathematics education and science bahwa matematika bukan hanya diperlukan untuk keperluan sendiri, tetapi dapat bermanfaat untuk ilmu-ilmu lainnya. Dengan kata lain matematika berperan sangat penting untuk ilmu-ilmu lain seperti sains dan teknologi. ${ }^{5}$

Menurut Anggraini Fitrianingtyas tentang jurnal mitra pendidikan bahwa hasil belajar adalah hasil yang telah dicapai oleh peserta didik dalam bentuk angka setelah diberikannya tes hasil belajar siswa selama

\footnotetext{
${ }^{1}$ Sriyanto, Mengobarkan Api Matematika, (Sukabumi: CV Jejak, 2017).

${ }^{2}$ Hasan Sastra Negara, Konsep Dasar Matematika Untuk PGSD, (Bandar Lampung: CV Anugrah Utama Raharja, 2014).

${ }^{3}$ Sitti Rahayu dan Wahyu Nur Hidayati, "Meningkatkan Hasil Belajar Matematika Melalui Penggunaan Media Bangun Ruang dan Bangun Datar Pada Siswa Kelas V SDN Jomin Barat 1 Kecamatan Kota Baru Kabupaten Karawang", Dalam Jurnal JPSD edisi no. 2, Vol. 4, September 2018.

${ }^{4}$ Hikmah, "Pengembangan Perangkat Pembelajaran Matematika Realistik pada Siswa Kelas V SD”, Dalam Jurnal Saintifik edisi no. 1, Vol. 3, Januari 2017.

${ }^{5}$ Muhammad Daut Siagian, "Kemampuan Koneksi Matematika Dalam Pembelajaran Matematika”, Dalam Journal of Mathematics Education and Science edisi no. 1, Vol. 2, Oktober 2016.
} 
proses pembelajaran. ${ }^{6}$ Hasil belajar pada mata pelajaran matematika pada dasarnya rendah karena dipengaruhi oleh beberapa faktor yaitu faktor internal atau dalam diri peserta didik dan faktor eksternal atau dari luar diri peserta didik. Faktor internal meliputi faktor fisiologis dan faktor psikologis. Sedangkan faktor eksternal meliputi faktor keluarga, faktor sekolah dan faktor masyarakat ketika siswa berinteraksi. Berikut adalah salah satu faktor yang dapat mempengaruhi hasil belajar siswa adalah siswa yang kurang tertarik mengikuti pembelajaran matematika, strategi pembelajaran yang diterapkan oleh guru kurang tepat dan kurangnya pengembangan kreativitas siswa selama mengikuti proses pembelajaran matematika. Berdasarkan Kriteria Ketuntasan Minimum (KKM) yang ditetapkan oleh sekolah dan guru mata pelajaran matematika adalah 75. Nilai siswa kelas IV pada mata pelajaran matematika pada materi bangun datar dengan persentase hasil belajar yaitu 50\% atau 21 siswa dengan nilai tidak tuntas. Hal ini terjadi karena banyak rumus yang harus dihafal oleh siswa, sehingga ditemui kesalahan pada siswa dalam mengerjakan soal bangun datar. Sedangkan dalam jurnal Ketut Sutarmi dan I Md Suarjana yang berjudul "Peningkatan Hasil Belajar Siswa Menggunakan Metode Problem Solving dalam Pembelajaran IPA" dijabarkan bahwa masalah dalam penelitian pada siklus I yaitu siswa belum mampu membuat pertanyaan sendiri, siswa kurang bekerja sama dalam diskusi kelompok, hasil diskusi kelompok hanya dikerjakan oleh satu atau dua orang siswa yang pintar atau paham pada soal tersebut dan siswa yang malas belajar bersikap acuh tak acuh dan tidak mau membaca serta mendengarkan hasil temuan temannya di kelompok lain. Pada siklus II dalam proses pembelajaran siswa sudah terbiasa dan telah terlatih belajar dengan mengikuti penerapan metode problem solving. ${ }^{7}$ Berdasarkan permasalahan, guru mampu merancang suatu metode pembelajaran yang dimana metode tersebut bisa membuat siswa lebih aktif guna melatih kemampuan berpikirnya. Salah satu metode yang digunakan adalah metode problem solving. Menurut Abdul Majid metode problem solving sendiri bukan digunakan sebagai metode mengajar saja tetapi juga merupakan suatu metode berfikir. ${ }^{8}$

Sejak adanya pandemi pemerintah melakukan berbagai cara untuk mencegah penyebaran virus corona. Cara ini adalah sebagai salah satu usaha pencegahan penyebaran covid-19. Pemeriah terus mengupayakan bagaimana pembelajaran agar tetap berlangsung seperti biasa. Menurut Adib Rifqi Setiawan dalam jurnal ilmu pendidikan bahwa pembelajaran jarak jauh adalah pembelajaran yang dilakukan dengan tidak bertatap muka secara langsung yaitu siswa dan pengajar tidak hadir secara fisik dengan bersamaan. Pembelajaran dilakukan dengan tidak bertatap muka secara langsung. ${ }^{9}$ Disisi lain menjaga pendidikan agar tetap berjalan

\footnotetext{
${ }^{6}$ Anggraini Fitrianingtyas, "Peningkatan Hasil Belajar IPA Melalui Model Discovery Learning Siswa Kelas IV SDN Gedanganak 02”, Dalam Jurnal Mitra Pendidikan edisi no. 6, Vol. 1, Agustus 2017.

${ }^{7}$ Ketut Sutarmi dan I Md Suarjana, "Peningkatan Hasil Belajar Siswa Menggunakan Metode Problem Solving dalam Pembelajaran IPA”, Dalam Jurnal Ilmiah Sekolah Dasar edsi no. 2, Vol. 1, 2017.

${ }^{8}$ Abdul Majid, Strategi Pembelajaran, (Bandung: PT Remaja Rosdakarya, 2016).

${ }^{9}$ Adib Rifqi Setiwan, "Lembar Kegiatan Literasi Saintifik untuk Pembelajaran Jarak Jauh Topik Penyakit Corona Virus (Covid-19)", Dalam Jurnal Ilmu Pendidikan edisi no. 1, Vol. 2, April 2020.
} 
dengan baik sesuai dengan instruksi pemerintah untuk belajar di rumah. Proses belajar di rumah pun memiliki ketentuan yaitu pembelajaran dapat dilakukan di rumah melalui pembelajaran jarak jauh yang dilaksanakan untuk memberikan pengalaman belajar yang proses pembelajaran lebih bermakna. Selain itu, aktivitas dan tugas pembelajaran dengan mempertimbangkan fasilitas yang ada di rumah. Menurut penelitian Firman dan Sari Rahayu Rahman tentang journal of educational science bahwa penggunaan internet dan teknologi dapat mempermudah penyampaian pengetahuan. ${ }^{10}$ Pihak sekolah dan siswa beserta orang tua membiasakan untuk menerapkan pembelajaran berbasis online. Menurut hasil penelitian Zainal Abidin, Rumansyah dan Kurniawan Arizona tentang jurnal ilmiah profesi pendidikan bahwa rata-rata hasil belajar yang diajarkan melalui metode pembelajaran online mengalami peningkatan yang lebih baik daripada ratarata hasil belajar yang diajar dengan metode konvensional. ${ }^{11}$ Guru harus mampu merancang pembelajaran agar pembelajaran berlangsung tersebut dapat berjalan secara efektif dengan menggunakan aplikasi yang tersedia.

Peneliti bermaksud untuk melakukan penelitian mengenai efektivitas metode problem solving terhadap hasil belajar matematika kelas IV SD Islam Al-Azhar 47 Samarinda pada masa pandemi covid-19. Pembelajaran online yang diterapkan tentunya dengan memadukan metode problem solving dengan berbagai aplikasi yang digunakan. Berdasarkan permasalahan tersebut maka perlu adanya pembelajaran yang efektif yang harus diterapkan. Kegiatan belajar mengajar dapat dikatakan efektif, jika hasil yang didapatkan pun jauh lebih bagus dari sebelumnya. Tujuan dari penelitian ini adalah untuk mengetahui seberapa besar metode problem solving efektif pada hasil belajar matematika kelas IV SD Islam Al-Azhar 47 Samarinda pada masa pandemi covid-19.

\section{METODE PENELITIAN}

Penelitian ini dilaksanakan di SD Islam Al-Azhar 47 Samarinda Provinsi Kalimantan Timur dengan subjek penelitian siswa kelas IV semester genap tahun pelajaran 2019/2020. Berdasarkan permasalahan yang diteliti, maka jenis penelitian yang digunakan adalah penelitian kuantitatif. Populasi dalam penelitian ini adalah seluruh siswa kelas IV SD Islam Al-Azhar 47 Samarinda yang berjumlah 42 siswa dari 2 kelas. Penelitian ini melibatkan dua kelas untuk diteliti, yaitu kelas eksperimen dan kelas kontrol. Adapun desainnya sebagai berikut:

${ }^{10}$ Firman dan Sari Rahayu Rahman, "Pembelajaran Online di Tengah Pandemi Covid-19”, Dalam Journal of Educational Science edisi no. 2, Vol. 02, Maret 2020.

11 Abidin Zainal, dkk, "Pembelajaran Online Berbasis Proyek Salah Satu Solusi Kegiatan Belajar Mengajar di Tengah Pandemi Covid-19”, Dalam Jurnal Ilmiah Profesi Pendidikan edisi no. 1, Vol. 5, Mei 2020. 
Tabel 1. Desain Penelitian

\begin{tabular}{|c|c|c|c|c|}
\hline Grup & Pretest & Perlakuan & Posttest & Kelas \\
\hline Eksperimen & $\mathrm{O}_{1}$ & $\mathrm{X}$ & $\mathrm{O}_{2}$ & IV A \\
\hline Kontrol & $\mathrm{O}_{3}$ & - & $\mathrm{O}_{4}$ & IV B \\
\hline
\end{tabular}

Keterangan :

$\mathrm{X}$ : Ada perlakuan

- : Tidak menerima perlakuan

$\mathrm{O}_{1}$ : Tes kemampuan awal pada kelompok eksperimen (pretest)

$\mathrm{O}_{2}$ : Tes kemampuan akhir pada kelompok eksperimen (posttest)

$\mathrm{O}_{3}$ : Tes kemampuan awal pada kelompok kontrol (pretest)

$\mathrm{O}_{4}$ : Tes kemampuan akhir pada kelompok kontrol (posttest)

Metode pengumpulan data penelitian meliputi observasi, tes dan dokumentasi. Sebelum melakukan eksperimen, dilakukan uji normalitas dan uji homogenitas terhadap data kemampuan awal matematika (pretest). Uji normalitas dilakukan dengan menggunakan metode Shapiro-Wilk dan uji homogenitas variansi populasi menggunakan uji levene dan uji hipotesis menggunakan uji independent $t .^{12}$

$$
\mathrm{t}_{\text {hitung }}=\frac{X 1-X 2}{\sqrt{\frac{(n 1-1) s 1^{2}+(n 2-1) s 2^{2}}{n 1+n 2-2}\left(\frac{1}{n 1}+\frac{1}{n 2}\right)}}
$$

dengan ketentuan $\mathrm{H}_{0}$ ditolak jika nilai t hitung $>\mathrm{t}$ tabel sebaliknya $\mathrm{H}_{\mathrm{a}}$ diterima jika nilai $\mathrm{t}$ hitung $<\mathrm{t}$ tabel.

\section{HASIL PENELITIAN DAN PEMBAHASAN}

Sebelum dilakukan uji hipotesis dengan menggunakan uji t, dilakukan uji prasyarat terhadap data penelitian untuk mengetahui data yang diperoleh berdistribusi normal atau tidak dan untuk mengetahui apakah sampel yang diambil memiliki variansi yang sama atau tidak. Dari hasil perhitungan uji normalitas dengan metode shapiro-wilk diperoleh:

Tabel 2. Hasil Uji Normalitas

\begin{tabular}{|c|c|c|c|}
\hline \multirow[t]{2}{*}{ Kelas } & \multicolumn{3}{|c|}{ Shapiro-Wilk } \\
\hline & Statistic & Df & Sig. \\
\hline $\begin{array}{r}\text { Pre-Test } \\
\text { Eksperimen }\end{array}$ & ,954 & 21 & , 409 \\
\hline $\begin{array}{r}\text { Post-Test } \\
\text { Eksperimen }\end{array}$ & ,916 & 21 &, 072 \\
\hline
\end{tabular}

${ }^{12}$ Sugiyono, Metode Penelitian Pendidikan Pendekatan Kuantitatif, Kualitatif dan $R \&$ \& , (Bandung: Alfabeta, 2017). 
Didink Agustien, Abdul Razak : Efektivitas Metode Problem Solving Terhadap Hasil Belajar Matematika Kelas IV SD Islam Al-Azhar 47 Samarinda Pada Masa Pandemi COVID-19

\begin{tabular}{|r|r|r|r|}
\hline Pre-Test &, 883 & 21 &, 016 \\
Kontrol &, 964 & 21 &, 594 \\
Post-Test & & & \\
Kontrol & & & \\
\hline
\end{tabular}

Berdasarkan tabel dapat diketahui bahwa hasil pretest kelompok eksperimen memiliki taraf signifikansi sebesar 0,409 dan hasil posttest kelompok eksperimen memiliki taraf signifikansi sebesar 0,72. Sedangkan hasil pretest kelompok kontrol memiliki taraf signifikansi sebesar 0,16 dan hasil posttest kelompok kontrol sebesar 0,594. Taraf signifikansi kedua kelompok lebih dari 0,05 yang artinya kelompok eksperimen dan kelompok kontrol berdistribusi normal. Adapun hasil uji homogenitas variansi populasi menggunakan uji levene diperoleh:

Tabel 3. Hasil Uji Homogenitas

\begin{tabular}{|ll|r|r|r|r|}
\hline & \multicolumn{1}{|c|}{$\begin{array}{c}\text { Levene } \\
\text { Statistic }\end{array}$} & df1 & \multicolumn{1}{c|}{ df2 } & \multicolumn{1}{l|}{ Sig. } \\
\hline & Based on Mean &, 012 & 1 & 40 &, 913 \\
& Based on Median &, 004 & 1 & 40 &, 953 \\
Hasil Belajar & Based on Median &, 004 & 1 & 38,937 &, 953 \\
Siswa & and with adjusted & & & & \\
& df & & & & \\
& Based on trimmed &, 014 & 1 & 40 &, 908 \\
& mean & & & & \\
\hline
\end{tabular}

Berdasarkan tabel di atas, dapat diketahui bahwa untuk uji homogenitas pada posttest kelompok eksperimen dan kelompok kontrol diperoleh nilai signifikansi sebesar 0,913. Adapun hasil uji independent t pretest pada kelompok eksperimen dan kelompok kontrol sebagai berikut:

Tabel 4. Hasil Uji Independent T Pretest Eksperimen dan Kontrol

\begin{tabular}{|c|c|c|c|c|}
\hline Variabel & Mean & T hitung & Sig (2-tailed) & Keterangan \\
\hline $\begin{array}{c}\text { Kelompok } \\
\text { Eksperimen }\end{array}$ & 67,52 & 1,263 & 0,214 & $\begin{array}{c}\text { Tidak ada } \\
\text { beda }\end{array}$ \\
\hline $\begin{array}{c}\text { Kelompok } \\
\text { Kontrol }\end{array}$ & 65,33 & 1,263 & & \\
\hline
\end{tabular}

Berdasarkan tabel di atas, hasil analisis untuk uji t menunjukkan bahwa nilai t sebesar 1,263 dan nilai signifikansi 0,214. Nilai signifikansi menyatakan lebih besar dari 0,05, maka dapat dinyatakan bahwa Ha ditolak dan Ho diterima, yang artinya tidak ada perbedaan yang signifikan hasil pretest kelompok eksperimen dan kelompok kontrol. Jadi dapat disimpulkan bahwa antara kelompok eksperimen dan kelompok kontrol memiliki kemampuan sama. Adapun hasil uji independent $\mathrm{t}$ posttest pada kelompok eksperimen dan kelompok kontrol sebagai berikut:

\section{Al-Madrasah: Jurnal Ilmiah Pendidikan Madrasah Ibtidaiyah} Vol. 5, No. 1, Juli-Desember 2020 
Tabel 5. Hasil Uji Independent T Posttest Eksperimen dan Kontrol

\begin{tabular}{|c|c|c|c|c|}
\hline Variabel & Mean & T hitung & Sig (2-tailed) & Keterangan \\
\hline $\begin{array}{c}\text { Kelompok } \\
\text { Eksperimen }\end{array}$ & 81,10 & 1,838 & \multirow{2}{*}{0,074} & $\begin{array}{c}\text { Ada } \\
\text { perbedaan }\end{array}$ \\
\hline $\begin{array}{c}\text { Kelompok } \\
\text { Kontrol }\end{array}$ & 75,62 & 1,838 & & \\
\hline
\end{tabular}

Berdasarkan tabel di atas, hasil analisis untuk uji t menunjukkan bahwa nilai $\mathrm{t}$ sebesar 1,838 dan nilai signifikansi 0,074. Nilai signifikansi menyatakan lebih kecil dari 0,05, maka dapat dinyatakan bahwa Ha diterima dan $\mathrm{H}_{0}$ ditolak. Dan dari hasil hitungan manual menunjukkan bahwa nilai t hitung sebesar 5,974 lebih besar dari $\mathrm{t}$ tabel sebesar 2,021. Jika nilai $\mathrm{t}$ hitung $>\mathrm{t}$ tabel maka dapat dikatakan signifikan. Berdasarkan analisis data dapat dikatakan bahwa hasil belajar matematika efektif dengan menggunakan metode problem solving pada kegiatan pembelajaran secara online. Menurut Emilia, Wasitohadi dan Theresia Sri Rahayu, dalam sebuah jurnal yang berjudul "Analisis Kesulitan Pemecahan Masalah Matematika di Sekolah Dasar Kelas 5TH" menguraikan bahwa pemecahan masalah adalah salah satu cara yang dapat digunakan guna meningkatkan keterampilan berpikir. Strategi pembelajaran yang digunakan dalam pembelajaran matematika mengenai pemecahan masalah adalah dengan strategi Polya. Berdasarkan penelitian, analisis deskriptif yang digunakan pada tujuh siswa sekolah dasar. Hasil penelitian menunjukkan bahwa, kesulitan yang menjadikan permasalahan pada soal matematika siswa sekolah dasar karena siswa tersebut merasa kurang yakin dalam memahami masalah dan menentukan konsep matematika yang akan digunakan. $^{13}$

Adapun deskripsi pembelajaran yang dilakukan dalam penggunaan metode problem solving secara online dalam pembelajaran matematika materi bangun datar adalah: kegiatan pra pembelajaran guru terlebih dahulu membuka pembelajaran melalui zoom. Kemudian guru mengecek kehadiran siswa dan memberi apersepsi materi yang akan disampaikan. Guru menjelaskan langkah-langkah pembelajaran dengan metode problem solving kepada siswa yaitu pada materi bangun datar. Sebelum memulai kegiatan inti, guru menutup pembelajaran melalui zoom. Guru memberikan soal pretest kepada siswa dengan waktu yang ditentukan. Soal pretest dapat dilihat siswa melalui google form dengan link yang dikirimkan guru melalui google classroom. Guru memberikan waktu 40 menit kepada siswa untuk mengerjakan soal pretest. Kemudian guru meminta siswa untuk mengirimkan hasil pretest yang telah mereka kerjakan melalui google classroom. Kemudian dilanjutkan pada kegiatan inti.

\footnotetext{
${ }^{13}$ Emilia, dkk, "Upaya Meningkatkan Hasil Belajar Siswa Dalam Pembelajaran Matematika Kelas V Dengan Menggunakan Metode Problem Solving”, Dalam Jurnal Basicedu edisi no. 1,Vol. 3, 2019.
} 
Didink Agustien, Abdul Razak : Efektivitas Metode Problem Solving Terhadap Hasil Belajar Matematika Kelas IV SD Islam Al-Azhar 47 Samarinda Pada Masa Pandemi COVID-19

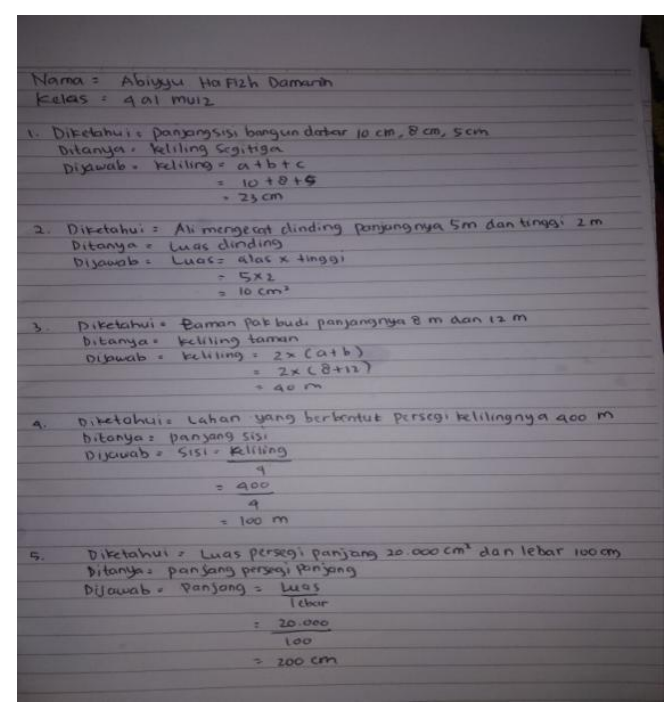

Hasil Pretest Kelas Eksperimen

Pada kegiatan inti guru membagikan video pembelajaran mengenai materi bangun datar melalui google classroom. Dan guru memberikan waktu 10 menit kepada siswa untuk memahami materi bangun datar tersebut.

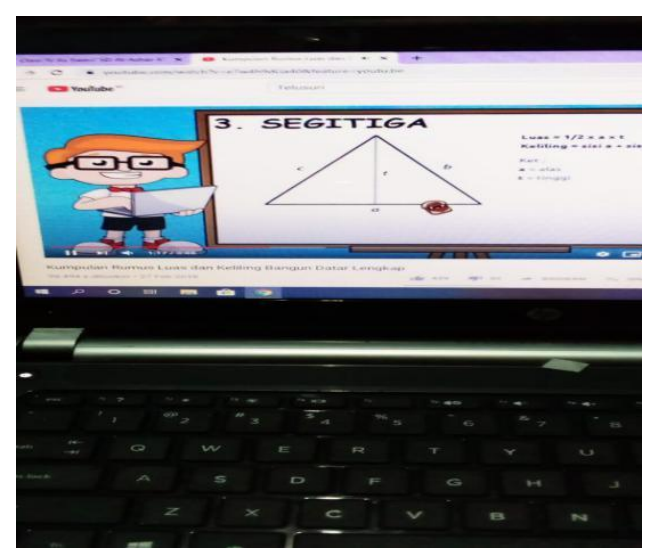

Video Pembelajaran

Kemudian guru melanjutkan kembali pembelajaran melalui zoom, guru memberikan permasalahan kepada siswa mengenai materi bangun datar dan membimbing siswa secara perlahan-lahan agar siswa mudah memahami masalah tersebut. 


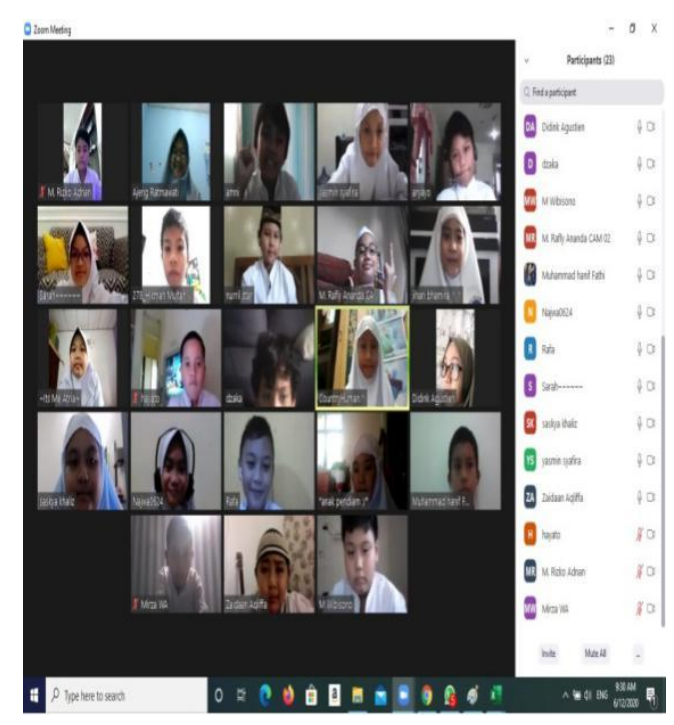

Pembelajaran Melalui Zoom

Kemudian guru meminta masing-masing siswa untuk mencari data atau keterangan yang dapat digunakan untuk memecahkan masalah. Masing-masing siswa menuliskan data atau keterangan yang dapat digunakan untuk memecahkan masalah.

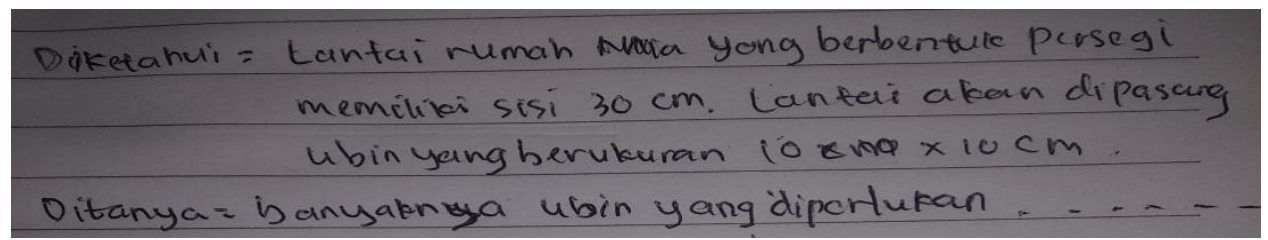

Data atau Keterangan yang dituliskan siswa

Setelah itu dengan bimbingan guru, guru meminta siswa untuk menetapkan jawaban sementara dari masalah bangun datar tersebut. Guru memberikan waktu sekitar 5 menit untuk mendapatkan hasil dari masalah tersebut.

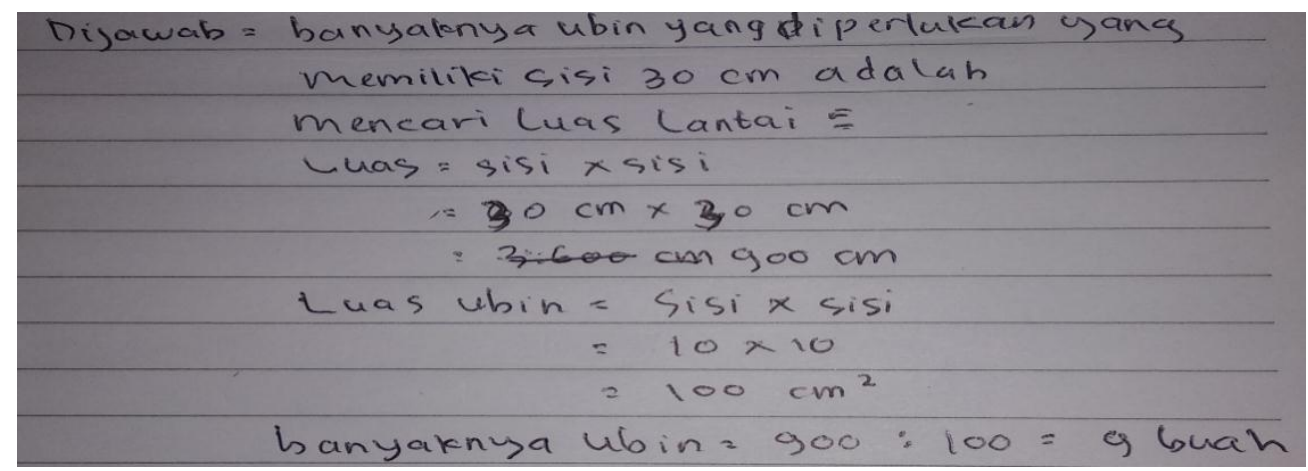

Jawaban Sementara yang dituliskan siswa

Setelah semua siswa menetapkan jawaban sementara, guru meminta siswa untuk melihatkan hasil jawaban sementara yang siswa tulis pada kertas untuk memastikan bahwa semua telah menyelesaikan permasalahan tersebut. Kemudian guru meminta salah satu siswa untuk menyajikan permasalahan tersebut. Guru memberikan kesempatan kepada siswa yang lain jika ada yang memiliki jawaban yang berbeda dan meminta 
siswa menyajikan permasalahan tersebut. Kemudian guru menguji kebenaran jawaban dari siswa apakah jawabannya sudah benar atau tidak.

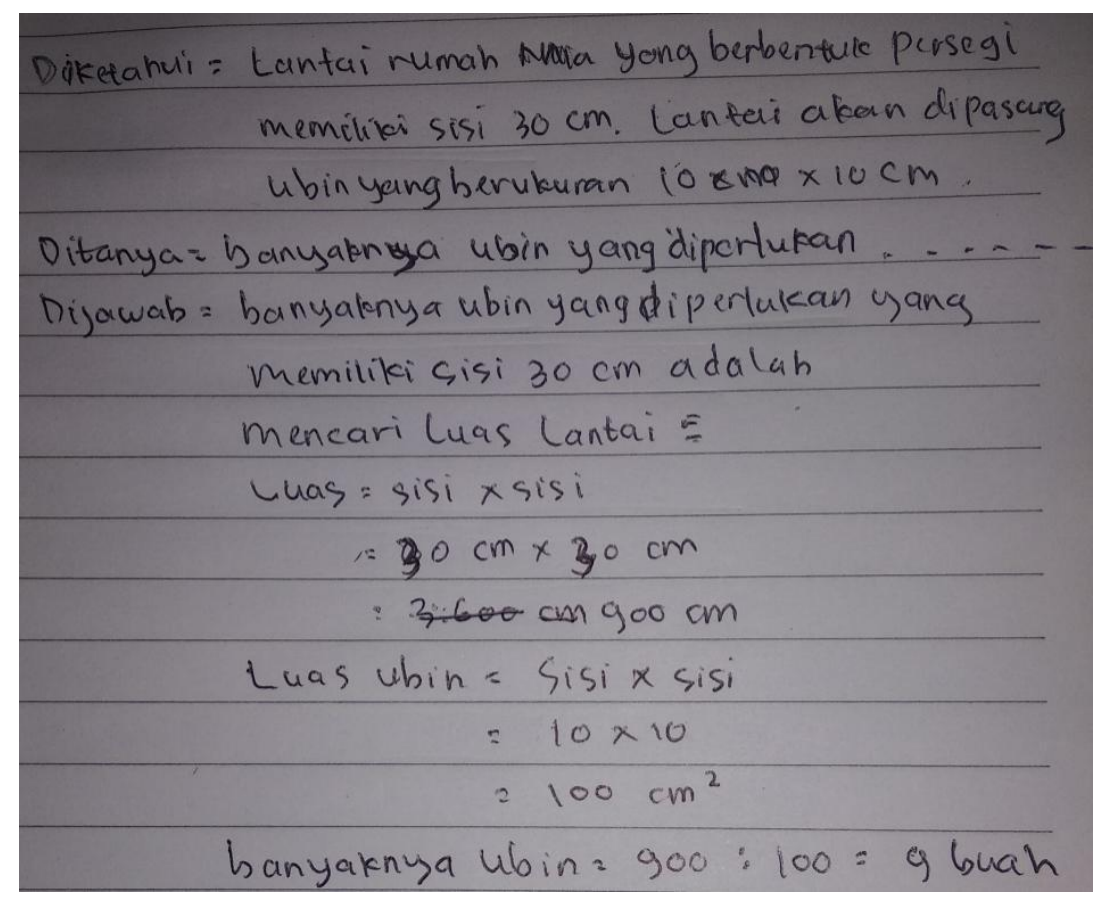

Hasil Jawaban Siswa yang diuji oleh guru

Ketika kebenaran jawaban sudah didapatkan. Dan yang terakhir guru dan siswa bersama-sama menarik kesimpulan.

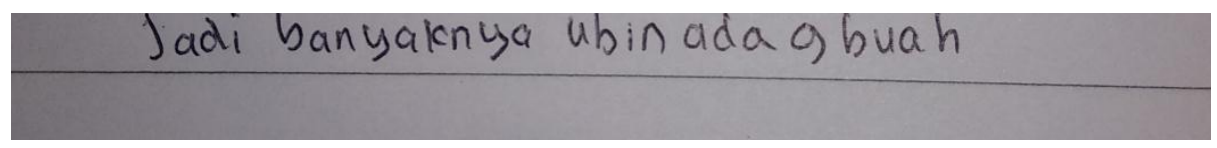

Kesimpulan dari Permasalahan

Guru meminta kepada masing-masing siswa setelah pembelajaran berakhir untuk mengirimkan hasil permasalahan yang sudah dipecahkan melalui google classroom. Setelah semua siswa memahami, guru memberikan permasalahan yang berbeda. Permasalahan yang diajukan oleh guru sebanyak 3 permasalahan yang harus dipecahkan secara bergantian sesuai dengan langkah-langkah pembelajaran sampai dengan waktu pembelajaran yang ditentukan. Begitupun pada pemecahan permasalahan yang kedua dan ketiga proses pembelajaran berlangsung dengan sama. Pada kegiatan inti proses pembelajaran berlangsung selama 40 menit. Untuk pertemuan kedua, ketiga dan keempat proses pembelajaran berlangsung sama, yang membedakan hanya pada pemberian pretest dan posttest. Pemberian pretest pada saat pertemuan pertama di awal pembelajaran atau sebelumnya perlakuan sedangkan pemberian pada posttest pada pertemuan kelima yang hanya memfokuskan siswa dalam mengerjakan posttest. Setelah pembelajaran inti berakhir, kemudian dilanjutkan pada kegiatan penutup. 
Pada kegiatan penutup guru mengadakan refleksi berupa tanya jawab mengenai materi bangun datar. Kemudian guru mengajak siswa untuk menyimpulkan bersama materi yang telah disampaikan oleh guru. Dan yang terakhir guru menutup pembelajaran melalui zoom. Guru mengirimkan lembar kerja siswa melalui google classroom dan memberikan waktu 10 menit untuk mengerjakan lembar kerja siswa tersebut.

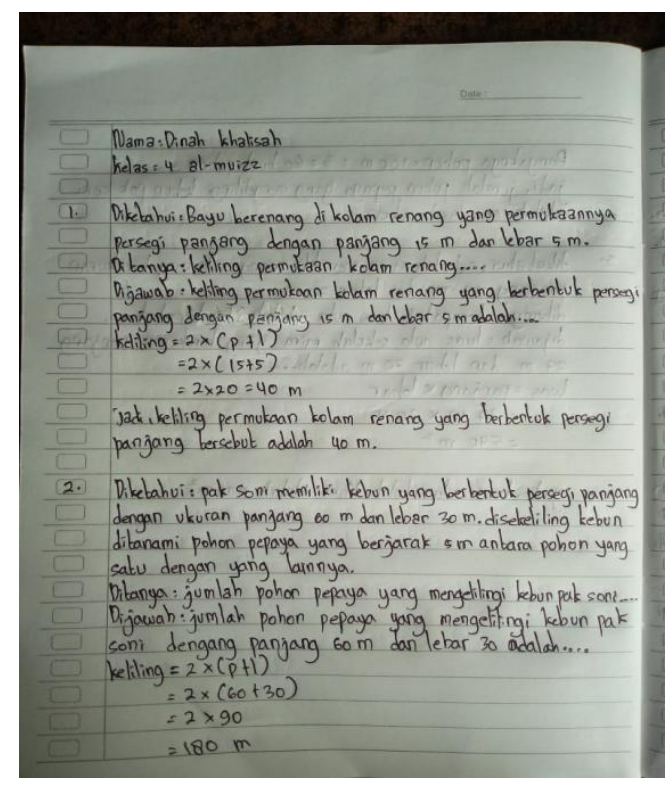

Hasil Lembar Kerja Siswa

Kemudian siswa mengirimkan hasil lembar kerja siswa melalui google classroom. Pelaksanaan dengan menggunakan metode problem solving pada kelompok eksperimen berlangsung dengan lancar dan siswa lebih mudah memahami materi bangun datar.

Dengan demikian peran guru sangat penting dan guru dituntut untuk merancang atau mendesain pembelajaran online yang membuat siswa lebih aktif dengan memanfaatkan media yang tepat dengan materi yang diajarkan. Menurut penelitian Luh Devi Herliandry, Nurhasanah, Maria Enjelina Subun dan Heru Kuswanto dalam jurnal teknologi pendidikan bahwa pembelajaran secara online memberikan kemudahan kepada peserta didik dalam menyampaikan informasi. Berbagai aplikasi pendukung yang bisa memulai pembelajaran secara berdiskusi hingga bertatap muka. Namun perlu di evaluasi kembali dan disesuaikan dengan kondisi setempat. Selain itu dengan mengingat kemampuan orang tua dalam penggunaan fasilitas pembelajaran online ini. ${ }^{14}$ pemanfaatan teknologi yang canggih sangat berperan dalam pelaksanaan pembelajaran jarak jauh di tengah pandemi covid-19. Penggunaan media sangat penting untuk diterapkannya pembelajaran. Menurut penelitian Abdul Razak dan Rumainur bahwa dengan adanya media dapat meningkatkan hasil belajar matematika. Pembelajaran dapat dikatakan efektif jika tujuan pembelajaran yang

\footnotetext{
${ }^{14}$ Luh Devi Herliandry, dkk, "Pembelajaran Pada Masa Pandemi Covid-19”, Dalam Jurnal Teknologi Pendidikan edisi no. 1, Vol. 22, April 2020.
} 
akan dicapai dalam suatu kegiatan terpenuhi dengan melalui bantuan media. ${ }^{15}$ Dengan melalui bantuan media dapat mempermudah proses belajar mengajar. Guru dapat mengaplikasikan media yang cocok digunakan melalui daring, seperti dengan video. Guru harus mampu membuat pembelajaran yang lebih bermakna dan mempermudah siswa dalam pemahaman mengenai materi yang disampaikan oleh guru. Menurut Roida Pakpahan dan Yuni Fitriani bahwa pembelajaran online adalah sistem belajar dengan bantuan alat yang mempermudah kegiatan belajar mengajar yang dapat terhubung melalui internet dan teknologi berbasis jaringan. ${ }^{16}$ Selanjutnya menurut Yulita Pujilestari bahwa teknologi informasi diartikan sebagai ilmu pengetahuan berbasis komputer yang membantu dalam memproses berbagai informasi dan perkembangannya sangat pesat. ${ }^{17}$

Menurut Wahyu Aji Fatma Dewi dalam jurnal ilmu pendidikan bahwa belajar dilakukan di rumah tidak menjadi masalah karena pembelajaran pun bisa dilakukan kapan dan dimana saja dengan bantuan ilmu teknologi yang sekarang ini memadai. Proses pembelajaran bisa terjadi di rumah, di sekolah maupun di masyarakat dengan dukungan fasilitas seperti internet. Berdasarkan hasil pretest kelas eksperimen yang menggunakan metode problem solving mengalami peningkatan. ${ }^{18}$ Dapat dilihat bahwa data hasil pretest kelas eksperimen disajikan dalam bentuk grafik berikut ini.

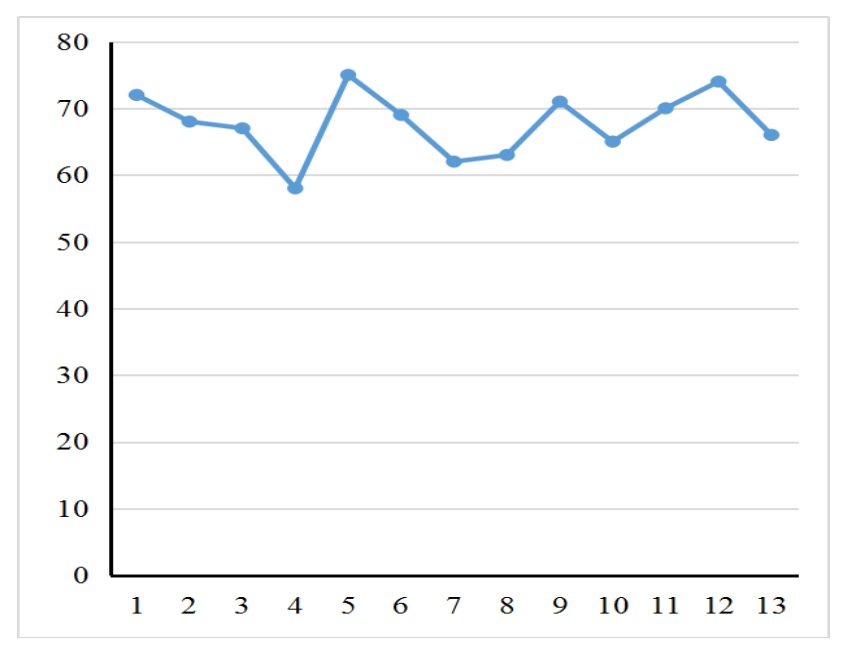

${ }^{15}$ Abdul Razak dan Rumainur, "Efektivitas Penggunaan Multimedia Auto Play Etnik Kalimantan Timur Terhadap Hasil Belajar Matematika SD Fastabiqul Khairat Kelas VI Di Kota Samarinda”, Dalam Jurnal JMIE edisi no. 2, Vol. 1, 2018.

${ }^{16}$ Roida Pakpahan dan Yuni Fitriani, “Analisa Pemanfaatan Teknologi Informasi dalam Pembelajaran Jarak Jauh di Tengah Pandemi Virus Corona Covid-19”, Dalam Journal of Information System, Applied, Management, Accounting and Researh edisi no. 2, Vol. 4, Mei 2020.

17 Yulita Pujilestari, "Dampak Positif Pembelajaran Online Dalam Sistem Pendidikan Indonesia Pasca Pandemi Covid-19”, Dalam Jurnal Buletin Hukum dan Keadilan edisi no. 1, Vol. 4, 2020.

${ }^{18}$ Wahyu Aji Fatma Dewi, "Dampak Covid-19 Terhadap Implementasi Pembelajaran Daring di Sekolah Dasar", Dalam Jurnal Ilmu Pendidikan edisi no. 1, Vol. 2, April 2020. 
Didink Agustien, Abdul Razak : Efektivitas Metode Problem Solving Terhadap Hasil Belajar Matematika Kelas IV SD Islam Al-Azhar 47 Samarinda Pada Masa Pandemi COVID-19

Dan data hasil pretest kelas kontrol disajikan dalam bentuk grefik berikut ini.

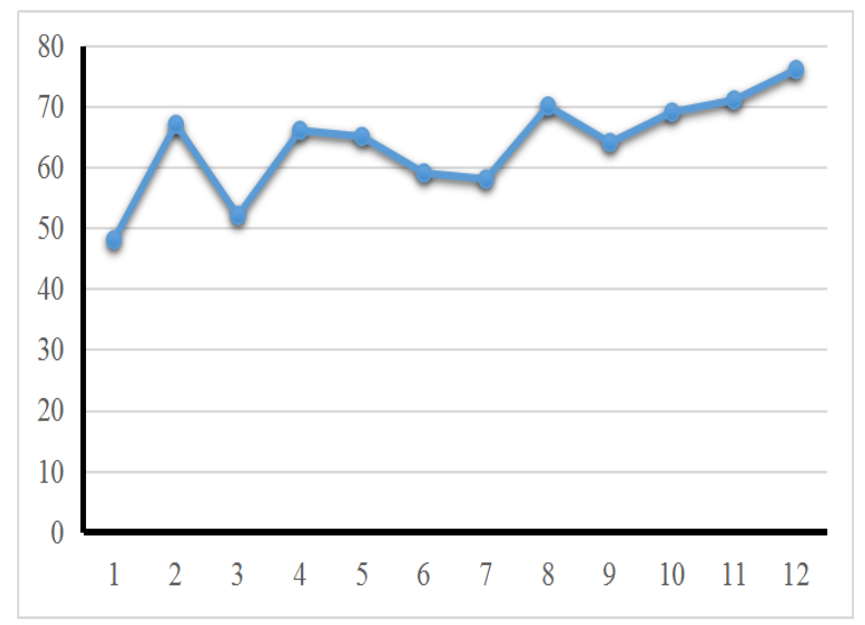

Hasil analisis data dengan uji t ( $t$-test) pada posttest atau tes akhir menujukkan ada perbedaan yang signifikan pada kelas eksperimen mendapatkan nilai rata-rata sebesar 81,10 dengan persentase $20 \%$. Sedangkan kelas kontrol mendapatkan nilai rata-rata sebesar 75,62.

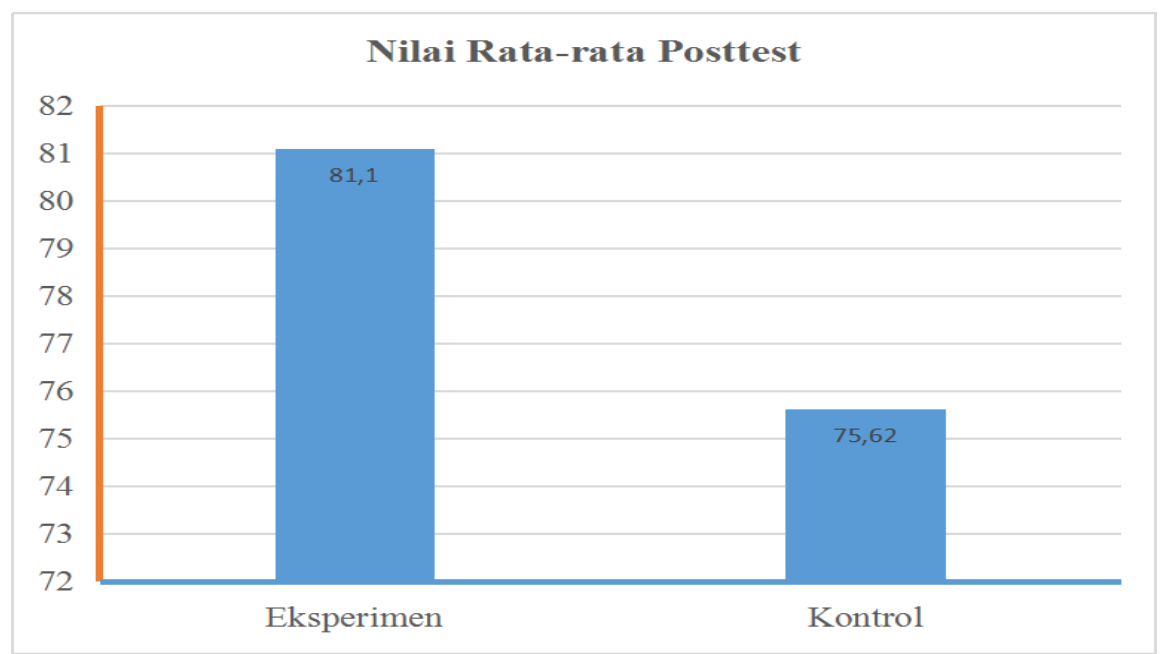

Dengan demikian dapat dinyatakan bahwa ada perbedaan hasil yang signifikan antara kelas ekperimen dan kelas kontrol. Dapat dilihat bahwa data hasil posttest dapat disajikan dalam bentuk grafik berikut ini.

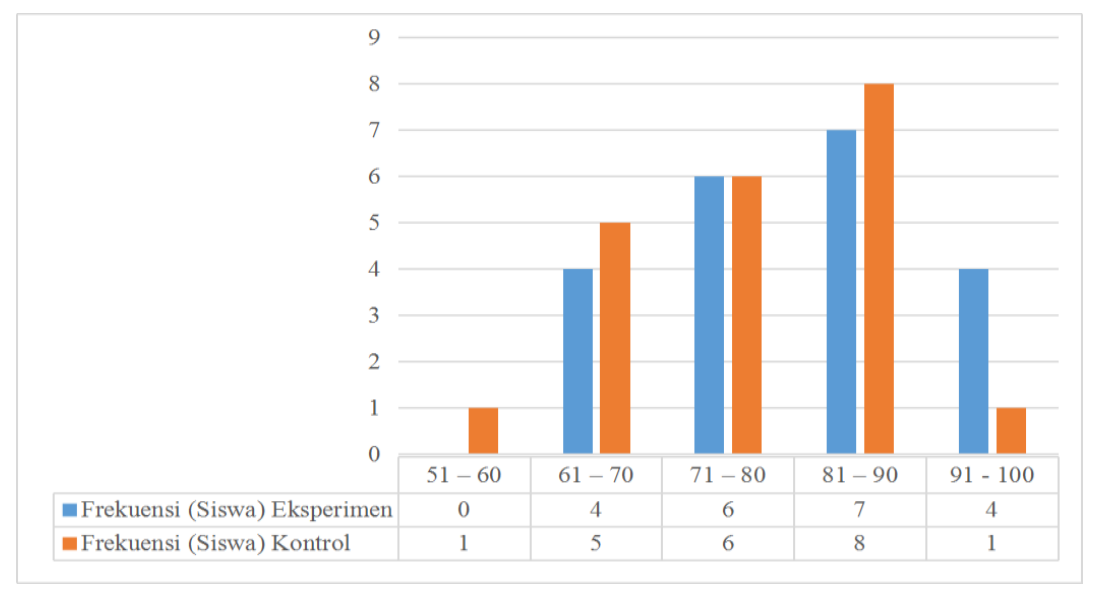

Al-Madrasah: Jurnal Ilmiah Pendidikan Madrasah Ibtidaiyah Vol. 5, No. 1, Juli-Desember 2020 
Pada hasil pretest kelompok eksperimen dan kelompok kontrol diperoleh t hitung sebesar 1,263 dan nilai signifikansi sebesar 0,214. Hal ini terlihat pada rata-rata nilai hasil belajar matematika metode problem solving lebih tinggi daripada nilai hasil belajar matematika metode konvensional. Menurut hasil penelitian Kisty Handayani, Bambang Suteng Sulasmono dan Eunice Widyanti Setyaningtyas bahwa hasil penelitian dengan menerapkan metode problem solving mengalami peningkatan. Dapat dilihat dari proses pembelajaran pada siklus I hingga siklus II. Pencapaian nilai rata-rata pada siklus I adalah 75 dan pada siklus II adalah 85. ${ }^{19}$ Maka dapat disimpulkan bahwa dengan menerapkan metode problem solving pembelajaran akan efektif dalam meningkatkan hasil belajar matematika pada siswa.

\section{SIMPULAN DAN SARAN}

Dapat disimpulkan bahwa terdapat perbedaan hasil belajar matematika antara siswa yang diberikan perlakuan dengan metode problem solving dengan siswa yang diberikan perlakuan dengan metode konvensional. Berdasarkan nilai rata-rata kelas eksperimen lebih tinggi dibandingkan kelas kontrol.

Dari simpulan, disarankan guru mampu bertindak kreatif dengan menggunakan metode-metode pembelajaran salah satunya dengan menerapkan metode problem solving. Sedangkan bagi selanjutnya, sebagai salah satu alternatif untuk melakukan penelitian dan penggunaan metode yang membuat siswa lebih aktif.

\section{DAFTAR PUSTAKA}

Abidin, Zainal, dkk. "Pembelajaran Online Berbasis Proyek Salah Satu Solusi Kegiatan Belajar Mengajar di Tengah Pandemi Covid-19”. Dalam Jurnal Ilmiah Profesi Pendidikan edisi no. 1. Vol. 5. Mei 2020.

Aji, Rizqon Halal Syah. "Dampak Covid-19 pada Pendidikan di Indonesia: Sekolah, Keterampilan, dan Proses Pembelajaran”. Dalam Jurnal Sosial dan Budaya Syar'i edisi no. 5. Vol. 7. 2020.

Dewi, Wahyu Aji Fatma. "Dampak Covid-19 Terhadap Implementasi Pembelajaran Daring di Sekolah Dasar". Dalam Jurnal Ilmu Pendidikan edisi no. 1. Vol. 2. April 2020.

Emilia. dkk, "Upaya Meningkatkan Hasil Belajar Siswa Dalam Pembelajaran Matematika Kelas V Dengan Menggunakan Metode Problem Solving”. Dalam Jurnal Basicedu edisi no. 1.Vol. 3. 2019.

Firman dan Rahman, Sari Rahayu. "Pembelajaran Online di Tengah Pandemi Covid-19". Dalam Journal of Educational Science edisi no. 2. Vol. 02. Maret 2020.

Fitrianingtyas, Anggraini. "Peningkatan Hasil Belajar IPA Melalui Model Discovery Learning Siswa Kelas IV SDN Gedanganak 02”. Dalam Jurnal Mitra Pendidikan edisi no. 6. Vol. 1. Agustus 2017.

Handayani, Kisty, dkk. "Implementasi Metode Pembelajaran Problem Solving Dalam Meningkatkan Kemampuan Berpikir Kreatif dan Hasil Belajar Matematika Siswa SD”. Dalam Jurnal Pendidikan dan Pemberdayaan Masyarakat edisi no. 2. Vol. 12. 2019.

\footnotetext{
${ }^{19}$ Kisty Handayani, dkk, "Implementasi Metode Pembelajaran Problem Solving Dalam Meningkatkan Kemampuan Berpikir Kreatif dan Hasil Belajar Matematika Siswa SD”, Dalam Jurnal Pendidikan dan Pemberdayaan Masyarakat edisi no. 2, Vol. 12, 2019.
} 
Herliandry, Luh Devi, dkk. "Pembelajaran Pada Masa Pandemi Covid-19". Dalam Jurnal Teknologi Pendidikan edisi no. 1. Vol. 22. April 2020.

Hikmah. "Pengembangan Perangkat Pembelajaran Matematika Realistik pada Siswa Kelas V SD". Dalam Jurnal Saintifik edisi no. 1. Vol. 3. Januari 2017.

Majid, Abdul. Strategi Pembelajaran. Bandung: PT Remaja Rosdakarya. 2016.

Negara, Hasan Sastra. Konsep Dasar Matematika Untuk PGSD. Bandar Lampung: CV Anugrah Utama Raharja. 2014.

Pakpahan, Roida dan Fitriani, Yuni. "Analisa Pemanfaatan Teknologi Informasi dalam Pembelajaran Jarak Jauh di Tengah Pandemi Virus Corona Covid-19". Dalam Journal of Information System, Applied, Management, Accounting and Researh edisi no. 2. Vol. 4. Mei 2020.

Pujilestari, Yulita. "Dampak Positif Pembelajaran Online Dalam Sistem Pendidikan Indonesia Pasca Pandemi Covid-19". Dalam Jurnal Buletin Hukum dan Keadilan edisi no. 1. Vol. 4. 2020.

Rahayu, Sitti dan Hidayati, Wahyu Nur. "Meningkatkan Hasil Belajar Matematika Melalui Penggunaan Media Bangun Ruang dan Bangun Datar Pada Siswa Kelas V SDN Jomin Barat 1 Kecamatan Kota Baru Kabupaten Karawang”. Dalam Jurnal JPSD edisi no. 2. Vol. 4. September 2018.

Razak, Abdul dan Rumainur. "Efektivitas Penggunaan Multimedia Auto Play Etnik Kalimantan Timur Terhadap Hasil Belajar Matematika SD Fastabiqul Khairat Kelas VI Di Kota Samarinda”. Dalam Jurnal JMIE edisi no. 2. Vol. 1. 2018.

Setiawan, Adib Rifqi. "Lembar Kegiatan Literasi Saintifik untuk Pembelajaran Jarak Jauh Topik Penyakit Corona Virus (Covid-19)". Dalam Jurnal Ilmu Pendidikan edisi no. 1. Vol. 2. April 2020.

Siagian, Muhammad Daut. "Kemampuan Koneksi Matematika Dalam Pembelajaran Matematika". Dalam Journal of Mathematics Education and Science edisi no. 1. Vol. 2. Oktober 2016.

Sriyanto. Mengobarkan Api Matematika. Sukabumi: CV Jejak. 2017.

Sugiyono. Metode Penelitian Pendidikan Pendekatan Kuantitatif, Kualitatif dan $R \&$ \& . Bandung: Alfabeta. 2017.

Sutarmi, Ketut dan Suarjana, I Md. "Peningkatan Hasil Belajar Siswa Menggunakan Metode Problem Solving dalam Pembelajaran IPA”. Dalam Jurnal Ilmiah Sekolah Dasar edsi no. 2. Vol. 1. 2017. 